\title{
WĘZLOWE PROBLEMY STOSOWANIA PRAWA PRYWATNEGO W SEKTORZE PUBLICZNYM
}

\section{WSTĘP}

Sektor publiczny ${ }^{1}$ przynajmniej od kilkudziesięciu lat w naszej euroatlantyckiej cywilizacji ma tendencję do nieustannego rozszerzania się, a w ślad za tym rośnie zależność współczesnej jednostki od państwa ${ }^{2}$. W konsekwencji można wyróżnić, obok trzech tradycyjnych płaszczyzn stosowania instrumentów wypracowanych w cywilistyce, czyli tzw. obrotu powszechnego, obrotu profesjonalnego i obrotu konsumenckiego, jeszcze sektor publiczny.

$\mathrm{W}$ ostatnich dziesięcioleciach, np. w związku ze zjawiskiem prywatyzacji zadań publicznych, a także decentralizacją administracji publicznej, pojawiło się wiele instytucji prawnych o charakterze eklektycznym, w których występuja przejawy zarówno rozwiązań cywilnoprawnych, jak i administracyjnoprawnych. Na przykład w nauce prawa administracyjnego pojawiło się pojęcie: „nietypowe podmioty administrujące”. Chodzi tutaj głównie o państwowe jednostki organizacyjne wykorzystujące w swej działalności zarówno klasyczne formy administracyjnoprawne działania, jak i formy typowe dla prawa cywilnego ${ }^{3}$. Warto też wskazać zwiększającą się ilość mieszanych konstrukcji

${ }^{1}$ Należy w tym miejscu wyjaśnić, że pojęcie „sektor publiczny” rozumiem szeroko. W szczególności w moim rozumieniu jest to pojęcie szersze od pojęcia „sektor finansów publicznych” określonego w art. 9 ustawy z 27 sierpnia 2009 r. o finansach publicznych (Dz. U. 2013, poz. 885), obejmuje bowiem również działalność np. spółek komunalnych. Pojęcie „sektor publiczny” obejmuje cała sferę aktywności państwa i innych podmiotów publicznych. Dotyczy to więc zarówno stosunków między samymi podmiotami publicznymi, jak i między podmiotami publicznymi i prywatnymi. Należy przy tym zauważyć, że pojęcie „podmiot publiczny” (czy „podmiot prawa publicznego”) budzi wątpliwości, gdyż nie zostało zdefiniowane w polskim prawie. Autor przez to pojęcie rozumie państwo, a także jednostki organizacyjne pochodne w stosunku do państwa, takie jak państwowe osoby prawne i jednostki samorządu terytorialnego.

${ }^{2}$ Dla przykładu z badań waszyngtońskiego think tanku Heritage Foundation wynika, że tzw. Index of Dependence on Government w USA permanentnie wzrasta i jest obecnie piętnastokrotnie wyższy niż na początku lat sześćdziesiątych XX w. Zob. D. B. Muhlhausen, P. D. Tyrell, The 2013 Index of Dependence on Government, A Report of The Heritage Foundation, 21 November 2013.

${ }^{3}$ Zob. J. Jagielski, M. Wierzbowski, A. Wiktorowska, Nietypowe podmioty administrujace - kilka refleksji na tle organizacyjnych form wykonywania zadan publicznych, w: Podmioty administracji publicznej $i$ prawne formy ich dziatania. Studia $i$ materiaty $z$ konferencji naukowej 
prawnych, w których proces decyzyjny jest dwuetapowy. Najpierw podejmowana jest decyzja administracyjna (np. o przyznaniu pomocy), a następnie zawierana jest umowa o charakterze wykonawczym. Przykładem są tutaj m.in. procedury ubiegania się o granty badawcze ${ }^{4}$.

Już ten fakt sprawia, że przeprowadzanie ścisłych rozłącznych podziałów między prawem publicznym i prywatnym jest zadaniem nie tylko niemożliwym do zrealizowania, ale i bezcelowym ${ }^{5}$.

Współczesna polska cywilistyka w stopniu niewystarczającym uwzględnia owe zjawiska i procesy. Można odnieść wrażenie, że dla większości cywilistów sektor publiczny traktowany jest nadal jak peryferie, a nawet jak swoista egzotyka w porównaniu z tradycyjnie pojmowanym obrotem cywilnoprawnym. Dowodzi tego np. fakt, że w całym wielotomowym i monumentalnym dziele System prawa prywatnego problematyce podziału systemu prawnego na prawo publiczne i prywatne, a także wybranym zagadnieniom stosowania prawa cywilnego w sektorze publicznym poświęcono zaledwie 20 stron (zob. t. 1). Przyczyn stosunkowo niewielkiego zainteresowania cywilistów problematyką stosowania prawa cywilnego w sektorze publicznym należy upatrywać m.in. w zaszłościach historycznych. W okresie PRL wyodrębniano zarówno pod względem normatywnym, jak i naukowym oraz dydaktycznym tzw. prawo obrotu uspołecznionego. W sensie normatywnym miał to być zbiór przepisów zawartych zarówno w Kodeksie cywilnym, jak i w licznych aktach prawnych niższego rzędu regulujących stosunki między tzw. jednostkami gospodarki uspołecznionej, a także jednostkami gospodarki uspołecznionej i osobami fizycznymi. Przeważał pogląd, że stosunki te mają charakter cywilnoprawny. W okresie PRL silna była bowiem zasada głosząca jedność prawa cywilnego. Zasada ta wówczas w znacznej części odnosiła się właśnie do owego obrotu uspołecznionego ${ }^{6}$. Wyrażał ją art. 1 Kodeksu cywilnego w pierwotnej wersji. Ze względu na upaństwowienie w okresie PRL praktycznie całej gospodarki, zdecydowana większość jednostek gospodarujących miały charakter państwowy. Jednostki gospodarki uspołecznionej wykonywały m.in. zadania, które w państwach gospodarki rynkowej zaliczane są do zadań użyteczności publicznej. Zadania te od dziesiątków lat wykonywane są w państwach gospodarki rynkowej przez specjalne przedsiębiorstwa publiczne, a umowy przez nie zawierane np. we Francji zaliczane są do umów administracyjnych ${ }^{7}$. Silne

poświęconej jubileuszowi 80-tych urodzin prof. E. Ochendowskiego, Toruń 15-16 listopada 2005 r., Toruń 2005.

${ }^{4}$ Zob. P. Stec, Umowy $w$ administracji. Studium cywilnoprawne, Warszawa 2013, s. 41; P. Sancewicz, Teoria dwóch stopni $w$ doktrynie niemieckiego prawa publicznego, „Studia Prawa Publicznego" 2013, nr 4, s. 127 i n.

${ }^{5}$ Zob. G. Jurgens, F. van Ommeren, The public-private divide in English and Dutch law: a multifunctional and context - dependant divide, „Cambridge Law Journal” 71(1), 2012, s. 172 i n.

${ }^{6}$ Zob. A. Stelmachowski, Wstep do teorii prawa cywilnego, Warszawa 1984, s. 35 i 58; A. Wolter, Prawo cywilne. Zarys części ogólnej, Warszawa 1967, s. 17.

${ }^{7}$ Zob. F. Grzegorczyk, Wptyw regulacji publicznoprawnych na swobodę kształtowania treści umów (statutów) spótek z udziałem Skarbu Państwa - w poszukiwaniu uzasadnienia, w: B. Gnela (red.), Ustawowe ograniczenia swobody umów. Zagadnienia wybrane, Warszawa 2010, s. 110-112. 
akcentowanie zasady jedności prawa cywilnego stało więc bezsprzecznie na przeszkodzie wykształceniu w poprzednim ustroju w Polsce np. umowy administracyjnoprawnej.

W środowisku prawniczym, a zwłaszcza w środowisku cywilistów, można często spotkać się z twierdzeniem, że prawo obrotu uspołecznionego jest reliktem poprzedniej słusznie minionej epoki i nie warto nawet do jego dorobku nawiąywać. W konsekwencji również ta sfera aktywności dawnych jednostek gospodarki uspołecznionej, którą obecnie nazywa się sektorem publicznym, zeszła w analizach cywilistycznych na dalszy plan. Tymczasem okazuje się, że pewne rozwiąania czy mechanizmy prawne powtarzaja się w czasie, i to niezależnie nawet od daleko idących przeobrażeń ustrojowych, jakie zaszły na przestrzeni ostatniego ćwierć wieku. Być może nietrafnie pewne instytucje uznano za relikt poprzedniego ustroju, gdyż praktyka pokazuje, iż dają one o sobie znać również w nowych realiach ${ }^{8}$. Przykładami są tutaj specjalna zdolność prawna osób prawnych uregulowana w nieobowiąującym od 1990 r. art. 36 k.c. czy też występujące w poprzednim systemie umowy o dofinansowanie różnego rodzaju przedsięwzięć. Przykładem są umowy, na podstawie których państwo realizowało pomoc tzw. gospodarstwom ekonomicznie słabym. Umowy te, zawierane w latach sześćdziesiątych XX w. przez organy administracji działające w imieniu Skarbu Państwa z rolnikami, będące podstawą udzielania szeroko pojętej i wielorodzajowej pomocy majątkowej, miały konstrukcję przypominająca dzisiejsze umowy zawierane przez organy władzy publicznej z tzw. beneficjentami o dofinansowanie tzw. projektów ${ }^{9}$. Dlatego zgadzam się, że dawne prawo obrotu uspołecznionego przynajmniej częściowo może być traktowane jako pierwowzór dzisiejszego prawa umów w administracji publicznej $^{10}$, a także jako źródło inspiracji dla jego rozwoju, podobnie jak np. niektóre dawne jednostki gospodarki uspołecznionej mogą być traktowane częściowo jako pierwowzór dzisiejszych spółek komunalnych ${ }^{11}$.

Doświadczenia z okresu PRL mimowolnie wywarły swoje piętno i nadal w jakimś stopniu wpływają na rozwój zarówno prawa prywatnego, jak i administracyjnego. Na pewno nie można tego faktu lekceważyć, gdy się analizuje polską specyfikę posługiwania się przez administrację umową czy innymi instytucjami cywilnoprawnymi. Na pewno nie można też tych zaszłości historycznych lekceważyć, gdy się analizuje polska specyfikę podziału na prawo publiczne i prywatne. W szczególności prawo publiczne w warunkach polskich nie obejmuje tak szerokiego spektrum stosunków społecznych jak np. we Francji. W konsekwencji zaszczepianie na grunt polski rozwiązań niemieckich czy francuskich w dziedzinie np. umów w administracji bez uwzględnienia tej specyfiki nie byłoby wskazane.

\footnotetext{
${ }^{8} \mathrm{Na}$ to zjawisko zwraca uwagę P. Stec, pisząc np. o „prawie obrotu uspołecznionego jako pierwowzorze współczesnej konstrukcji umów w administracji”. Zob. P. Stec, op. cit., s. 146.

9 Zob. A. Stelmachowski, op. cit., s. 30.

10 Zob. P. Stec, op. cit., s. 105.

11 Zob. R. Szczepaniak, Podmiotowość prawna spótki komunalnej, „Samorząd Terytorialny” 2013, z. 5, s. 34-41.
} 
Z powyżej wskazanych przyczyn wystapiła w polskiej nauce prawa pewna luka w badaniach nad stosowaniem prawa cywilnego w sektorze publicznym. $\mathrm{Z}$ jednej strony silnie akcentowana zasada jedności prawa cywilnego stała w jakimś sensie na przeszkodzie wykształceniu przez administratywistów np. koncepcji umowy administracyjnoprawnej oraz badaniom nad stosowaniem innych instytucji cywilistycznych w sektorze publicznym, z drugiej natomiast na skutek programowego wręcz zerwania przez cywilistykę po transformacji ustrojowej z dorobkiem prawa obrotu uspołecznionego, badania nad stosowaniem w sektorze publicznym instytucji cywilistycznych nie były przez cywilistów prowadzone.

\section{PROBLEMY NATURY METODOLOGICZNEJ}

\section{Podział na prawo publiczne i prywatne jako przyczyna „barier w naszym myśleniu o prawie"}

\subsection{Absolutyzowanie tego podziału}

Kwestia możliwości stosowania prawa prywatnego w sektorze publicznym nierozerwalnie wiąże się z zagadnieniem podziału na prawo publiczne i prywatne. Przy czym należy stanowczo podkreślić fakt, gdyż ma on znaczenie w wymiarze metodologicznym, że podział ten nie odnosi się tylko do systemu prawnego, lecz dotyczy również nauki prawa ${ }^{12}$.

Zdaniem niektórych przynajmniej teoretyków mamy tu do czynienia z podziałem, który wynika z samej natury prawa ${ }^{13}$. O prawdziwości tego twierdzenia może świadczyć niezwykła wręcz żywotność tego podziału. Nie tylko odrodził się w całej pełni w byłych państwach socjalistycznych, w tym również w Polsce po okresie dominacji socjalistycznej teorii państwa i prawa, negujacej co do zasady jego sensowność, lecz - co jest niezwykle charakterystyczne - doszedł do głosu także w państwach anglosaskich ${ }^{14}$. Jak wiadomo, tradycyjnie przeciwstawia się systemy prawne państw Europy kontynentalnej oraz państw anglosaskich, przy czym jedną z istotniejszych różnic między tymi systemami miało być nieprzeprowadzanie tego podziału w państwach zwanych anglosaskimi. W Europie kontynentalnej podział ten ze szczególną moca ujawnił się w drugiej połowie XIX w. wraz z kształtowaniem się zrębów prawa administracyjnego i jego nauki w dzisiejszym tego słowa znaczeniu. Wtedy też pojawiło się zjawisko absolutyzowania tego podziału, polegające na programowym wręcz negowaniu możliwości stosowania regulacji prawa cywilnego w sektorze publicznym. Dla XIX-wiecznych luminarzy rodzaceej się nauki prawa administracyjnego takie absolutyzowanie było swoistym odruchem obronnym, a podkreślanie wszelkich nieprzekraczalnych różnic między prawem prywatnym i publicznym kwestią wręcz egzystencjalnej wagi.

${ }^{12}$ J. Nowacki, Prawo publiczne - prawo prywatne, Katowice 1992, s. 12.

${ }_{13}$ Zob. O. Gierke, Deutsches Privatrecht, Bd. 1: Allgemeine Teil und Personenrecht, Leipzig 1895, s. 29; A. Ross, On Law and Justice, London 1958, s. 203.

${ }^{14}$ Zob. G. Jurgens, F. van Ommeren, op. cit., s. 172 i n. 
W tamtym czasie silne było przeświadczenie, że prawo cywilne stanowi tzw. prawo powszechne, albo przynajmniej część ogólną całego sytemu prawnego. Przekonanie to dobrze oddaje niemieckie powiedzenie Kein Zivilist, kein Jurist. W konsekwencji luminarze prawa administracyjnego musieli dopiero przekonać innych prawników do potrzeby wykształcenia takiej odrębnej gałęzi prawa równoważnej w stosunku do cywilistyki. Dla przykładu Otto Mayer przyjął charakterystyczną postawę metodologiczną. Świadom niedojrzałości doktryny administracyjnej w porównaniu z cywilistyką niemiecką rozwijał aparaturę pojęciową i instytucje prawa administracyjnego, czerpiąc $\mathrm{z}$ dorobku cywilistyki, co nie przeszkadzało mu jednocześnie kwestionować stosowania nawet w drodze analogii regulacji cywilnoprawnej do podmiotów prawa publicznego ${ }^{15}$. W ten sposób na zasadzie analogii do cywilistycznej aparatury pojęciowej i cywilistycznych instytucji w Niemczech i we Francji kształtowały się pojęcia mienia publicznego i własności publicznej, umów publicznoprawnych, administracyjnoprawnych oświadczeń woli (np. pełnomocnictwa administracyjnego) czy sui generis reżimu odpowiedzialności odszkodowawczej administracji. Proces rozwijania owych paralelnych instytucji uwidocznił się zwłaszcza we Francji w drodze orzecznictwa Rady Stanu oraz poglądów doktryny ${ }^{16}$. Uważa się, że czasy absolutyzowania tego podziału odeszły już w przeszłośćc ${ }^{17}$. Niemniej w dalszym ciagu w środowisku prawniczym możemy natrafić na przejawy myślenia typowego dla okresu absolutyzowania. Do takiego wniosku skłania np. terminologia niejednokrotnie używana w kręgach prawników, zwłaszcza administratywistów, zarówno w Polsce, jak i za granicą ${ }^{18}$. Żywotność tego podziału sprawiła, że odcisną on głębokie piętno na świadomości współczesnych prawników. Zauważalne jest to w działalności orzeczniczej sądów i organów administracji, a także w koncepcjach teoretycznych.

Nie zamierzam programowo negować sensowności tego podziału. Należy jednak stwierdzić, że analiza prowadzi do wniosku, iż pod wpływem absolutyzowania owego podziału - jak by to powiedziała Ewa Eętowska - wytworzyła

${ }_{15}$ Zob. O. Mayer, Deutsches Verwaltungsrecht, Bd. 1, Berlin 1921, s. 117; zob. na ten temat także H. de Wall, Die Anwendbarkeit privatrechtlicher Vorschriften im Verwaltungsrecht, Tübingen 1999, s. 13-15.

${ }_{16}$ Zob. F. Zylber, Odpowiedzialność cywilna za szkody wyrzqdzone przez działalność wtadz publicznych $w$ prawie francuskim, Warszawa 1930, s. 2 i n.

${ }^{17}$ Sformułowanie „absolutyzowanie podziału na prawo publiczne i prywatne” występuje w literaturze niemieckiej dla nazwania zjawiska wyolbrzymiania znaczenia tego podziału, zob. H. de Wall, op. cit., s. 61.

${ }_{18}$ Można np. usłyszeć z ust administratywistów zdania o „ekspansji doktryny prawa cywilnego na obszar stosunków między administracją publiczną a jednostkami gospodarczymi”, o „arbitralnym "przywłaszczaniu" przez prawo cywilne i jego naukę form umownych, których jedna ze stron był organ administracji państwowej”. Zob. np. W. Taras, A. Wróbel, W sprawie jednolitej koncepcji umów publicznych, w: E. Knosala, A. Matan, G. Łaszczyca (red.), Prawo administracyjne w okresie transformacji ustrojowej, Kraków 1999, s. 122. Z kolei cywiliści nie pozostają dłużni, stawiając zarzut „publicyzacji prawa cywilnego”. Interesujące przykłady takiej postawy zarówno administratywistów, jak i cywilistów we Francji podała M. Lemonnier w referacie pt. „Prawo prywatne - prawo publiczne - recepcja przy użyciu metody porównawczej”, wygłoszonym 22 kwietnia 2016 r. na ogólnopolskiej konferencji naukowej „Instytucje prawa prywatnego w służbie prawa publicznego - nadużycie czy konieczność ?”, zorganizowanej przez Uniwersytet Warmińsko-Mazurski w Olsztynie. 
się jedna z poważniejszych „barier w naszym myśleniu o prawie”"19. Bariery takie, nazywane przez autorkę „zdezaktualizowanymi stereotypami prawniczego myślenia”, „osłabiają wrażliwości sądów i ich hermeneutyczne umiejętności w zakresie odczytania tekstu prawa”, „[...] dostrzegania wielowymiarowości systemu prawnego, na który składają się nie tylko przepisy, ale także niepisane zasady, konstytucyjne standardy"20. Ponadto absolutyzowanie tego podziału przyczynia się do wewnętrznej dezintegracji systemu prawnego, a w efekcie osłabienia jego spójności.

Jak zostało wyżej wskazane, podział ten dotyczy nie tylko samego systemu prawnego, ale i nauki prawa. Ten fakt dodatkowo wzmacnia siłę jego oddziaływania. Nastapiło swego rodzaju dorozumiane „rozdzielenie strefy aktywności” między tzw. cywilistów i przedstawicieli nauki prawa publicznego, w tym zwłaszcza administratywistów, czyli usytuowanych w odrębnych katedrach akademickich naukowców, tak jakby dzielili między siebie strefy wpływów. Owe podziały są najczęściej respektowane. Niekiedy można nawet odnieść wrażenie, że poruszanie przez cywilistę tematyki z zakresu szeroko pojętej administracji publicznej nie jest mile widziane przez administratywistów i vice versa. Przejawy takiej postawy spotykane sa w tych wszystkich państwach, w których podział na prawo prywatne i publiczne tradycyjnie jest mocno zarysowany ${ }^{21}$.

\subsection{Niedychotomiczność, multifunkcjonalność i kontekstowość tego podziału}

Wciąż dostrzegany schematyzm myślenia prawniczego typowy dla absolutyzowania omawianego podziału cechuje się nie zawsze wysłowionym przekonaniem, że mamy do czynienia z podziałem o charakterze dychotomicznym, tzn. logicznym, a więc rozłącznym. W tego rodzaju przeciwstawieniu prawa publicznego i prywatnego bezsprzecznie kryje się tęsknota za tworzeniem czystych logicznie konstrukcji niczym algorytmów znajdujaccych zastosowanie bez wyjątku we wszystkich przypadkach. Prawnicy od czasów studiów w większości państw Europy kontynentalnej wpajane mają założenie o dychotomii podziału na prawo publiczne i prywatne ${ }^{22}$. Przynajmniej takie ujęcie stosunkowo często występuje w edukacji akademickiej. Tymczasem wydaje się, że postrzeganie podziału na prawo publiczne i prywatne jako podziału dychotomicznego jest jednym z najbardziej istotnych błędów metodologicznych w naukach prawnych.

W ostatnich latach dość przekonująco wykazano, że podział na prawo publiczne i prywatne nie ma charakteru dychotomicznego; w gruncie rzeczy jest

19 Zob. E. Łętowska, Bariery naszego myślenia o prawie w perspektywie integracji z Europa, „Państwo i Prawo” 1996, z. 4-5, s. 46.

20 Ibidem.

21 Zob. K. Opałek, Problemy „wewnętrznej” $i$ „zewnętrznej” integracji nauk prawnych, „Krakowskie Studia Prawnicze” 1968, z. 1-2, s. 10.

22 Zob. J. H. Merryman, The public law-private law distinction in European and American law, „Journal of Public Law (Emory Law Journal)” 17, 1968, s. 3. 
to podział nierozłaczny, ma on charakter multifunkcjonalny, a ponadto jego przeprowadzenie zależne jest od najróżniejszych kontekstów ${ }^{23}$, w tym również od uwarunkowań historycznych. Warto przypomnieć myśl Józefa Nowackiego, który zauważył, że rozumienie niekiedy pojawiającego się w tekście aktu prawnego przymiotnika „publiczny” (np. „interes publiczny”, „dobro publiczne”), jest całkowicie uzależnione od tego, co dany podmiot w danym kontekście ocenia jako publiczne"24.

Porzucenie założenia o dychotomicznym charakterze tego podziału jest metodologicznie bardziej płodne. Inspiruje do interdyscyplinarnych badań w obrębie szeroko pojętego prawoznawstwa i do otwarcia się na osiagnięcia prawników innych specjalności. Dla przykładu sami administratywiści przyznaja, że nie sa w stanie jak dotychczas stworzyć samodzielnej spójnej koncepcji umowy publicznoprawnej ${ }^{25}$. Wielce wskazane byłoby więc podjęcie wspólnych badań przez cywilistów i administratywistów nad zjawiskiem umowy w administracji. Jak wiadomo, to właśnie cywilistyka może pochwalić się największym dorobkiem w zakresie teorii umów.

Co jednak najważniejsze, niedychotomiczne spojrzenie na ten podział może się przyczynić do pełniejszej realizacji standardów demokratycznego państwa prawa, a przez to ochrony praw i wolności obywateli przed nadmierna i nieuzasadnioną ingerencją władzy publicznej. Ujęcie niedychotomiczne tego podziału skłania bowiem do wniosku, że władza publiczna przez wybór tzw. cywilnoprawnych form aktywności z umową na czele nie może uciec od wypracowanych w prawie publicznym i zapisanych w Konstytucji zasad regulujących jej funkcjonowanie. W przeszłości jak i obecnie możemy nadal spotkać się z próbami swoistej ucieczki administracji od prawa administracyjnego. Zjawisko takie występuje nie tylko w Polsce ${ }^{26}$. Tymczasem powinno się akcentować obowiązek respektowania przez administrację pewnych konstytucyjnych zasad demokratycznego państwa prawnego, stanowiących zaporę przed nadmierna ingerencją władzy publicznej w sferę praw i wolności obywateli, niezależnie od form, którymi w swej działalności administracja się posługuje. Łatwiej uzmysłowimy sobie tę konieczność, jeżeli uznamy, że podział na prawo publiczne i prywatne nie jest rozłączny (dychotomiczny), a w konsekwencji określone instytucje moga mieć charakter hybrydowy. Można w polskim orzecznictwie natrafić na przykłady, gdy sztywne dychotomiczne ujęcie tego podziału stwarzało swoisty gorset ograniczający zdolności sądu do poszukiwania najbardziej słusznego rozstrzygnięcia ${ }^{27}$.

${ }^{23}$ Zob. G. Jurgens, F. van Ommeren, op. cit., s. 172 i n.

${ }_{24}$ Zob. J. Nowacki, op. cit., s. 107.

25 Zob. W. Taras, A. Wróbel, op. cit., s. 124.

${ }_{26}$ To obrazowe sformułowanie zostało zaczerpnięte z literatury niemieckiej („Flucht vor dem Staatsrecht”, „Flucht ins Privatrecht”). Zob. na ten temat B. Binder, L. Fröhler, Die Haftung der Gemeinden für ausgegliederte Unternehmungen, Linz 1982, s. 13; U. Stelkens, The public-private law divide. Annual Report 2010, „Ius Publicum Network Review” November, 2011, s. 6.

${ }_{27}$ Zob. R. Szczepaniak, Zagadnienie praw podmiotowych na styku prawa prywatnego $i$ publicznego. Rozważania de lege ferenda na przykładzie opłat należnych komornikowi, „Ruch Prawniczy, Ekonomiczny i Socjologiczny” 76, 2014, z. 3, zwłaszcza s. 75-77, oraz idem, W zaklętym kręgu podziału na prawo publiczne i prywatne, „Studia Prawa Prywatnego” 2015, z. 3, s. 39 i n. 


\section{Stereotypy narosłe wokół podziału na prawo publiczne i prawo prywatne}

Jeszcze raz należy odwołać się do myśli E. Łętowskiej, która łączy bariery $\mathrm{w}$ naszym myśleniu o prawie $\mathrm{z}$,zdezaktualizowanymi stereotypami prawniczego myślenia”. Do najważniejszych takich stereotypów narosłych wokół podziału na prawo publiczne i prywatne zaliczam:

- stereotyp „dobrego prawa cywilnego" $\mathrm{i}$,złego prawo administracyjnego”"28,

- stereotyp umowy jako instrumentu regulowania stosunków społecznych zawsze lepszego od decyzji administracyjnej,

- stereotyp spółki prawa handlowego jako jednostki organizacyjnej zawsze lepszej od zakładu budżetowego.

Kultywowanie tych stereotypów może prowadzić do szeregu zjawisk niekorzystnych społecznie, w tym nadużyć ze strony władzy publicznej i najróżniejszych manipulacji. Niejednokrotnie można natrafić na przejawy swoistej socjotechniki uprawianej przez państwo, a w szczególności ustawodawcę, polegającej na sui generis żonglowaniu cywilnoprawną i administracyjnoprawna metoda regulacji stosunków społecznych. Skoro prawo cywilne w powszechnym acz stereotypowym odczuciu na tle prawa administracyjnego oceniane jest jako „dobre prawo”, jako wyraz wolności i równości stron, sam fakt wskazania przez ustawodawcę umowy jako formy działania administracji postrzegany jest $\mathrm{z}$ reguły jako postęp i wyraz partnerskiego traktowania jednostek w relacji do władzy publicznej. Umowa wszak jest klasycznym instrumentem cywilnoprawnej metody regulacji. Tymczasem, jak trafnie zauważają administratywiści, w praktyce niejednokrotnie się okazuje, że posłużenie się przez administrację publiczna forma umowy nawet pogarsza sytuację prawną obywatela; w niektórych przypadkach jest ona słabsza niż sytuacja prawna adresata decyzji administracyjnej29. Swoiste „zadekretowanie przez ustawodawcę umowy jako instrumentu regulacji stosunków społecznych" może kreować fikcję cywilnoprawnej równości stron ${ }^{30}$, a przede wszystkim powodować wspomnianą wyżej ucieczkę administracji od konstytucyjnych standardów demokratycznego państwa prawa.

Dla posłużenia się przez ustawodawcę metodą cywilnoprawną wymagane jest zaistnienie określonych uwarunkowań społecznych. W szczególności musi zaistnieć taka sytuacja, gdy istnieje pewien minimalny poziom autonomii stron oraz brak bezpośredniego przymusu ze strony organów władzy publicz-

${ }^{28} \mathrm{~W}$ przeszłości najdobitniej istnienie takiego stereotypu akcentowali E. Łętowska i J. Łętowski. Zob. E. Łętowska, Prawo cywilne a prawo administracyjne. Razem ale nie do spótki. „Dobre” prawo cywilne, „zte” prawo administracyjne, w: A. Mączyński M. Pazdan, A. Szpunar (red.), Rozprawy z polskiego i europejskiego prawa prywatnego. Księga pamiatkowa ofiarowana profesorowi Józefowi Skapskiemu, Kraków 1994, s. 221; J. Łętowski, Au carrefour de l'administration contemporaine, Wrocław-Warszawa-Kraków-Gdańsk-Łódź 1990, s. 84.

${ }^{29}$ W. Chróścielewski, Imperium a gestia $w$ działaniach administracji publicznej, „Państwo i Prawo" 1995, z. 6, s. 56 i n.

${ }^{30}$ Zob. wyrok TK z 27 maja 2014 r., P 51/13, Dz. U. 2014, poz. 735 z glosa R. Szczepaniak, Granice cywilnoprawnej metody regulacji. Glosa do wyroku TK $z 27$ maja 2014 r. P 51/13, Dz. U. 2014, poz. 735, „Państwo i Prawo” 2015, z. 12. 
nej ${ }^{31}$. Cała różnica między prawem prywatnym i publicznym nie sprowadza się, wbrew wysuwanym niekiedy twierdzeniom, jedynie do dowolnie przyjętej przez ustawodawcę metody regulacji w sensie technicznym. To prawda, że prawo cywilne obecnie rozumiane jest już inaczej niż w okresie XIX-wiecznego liberalizmu. W szczególności prawo zobowiązań od dawna już nie jest urzeczywistnieniem niemal niczym nieskrepowanej woli stron ${ }^{32}$. Niemniej prawo cywilne to coś więcej niż sama technika regulacji, którą ustawodawca może się posługiwać dowolnie i zamiennie z metodą administracyjnoprawną. Jeżeli nie występuje wskazana wyżej minimalna autonomia stron, zastosowanie przez ustawodawcę cywilnoprawnej metody regulacji staje się kontrskuteczne z punktu widzenia konstytucyjnych gwarancji jednostki, a rozwiązania cywilnoprawne przepoczwarzają się w swoją karykaturę ${ }^{33}$.

Z kolei stereotyp spółki prawa handlowego jako jednostki organizacyjnej lepszej, bardziej efektywnej, by nie powiedzieć naiwnie - nowocześniejszej od zakładu budżetowego jest najczęściej wynikiem niezrozumienia istoty zadań jednostek samorządu terytorialnego w ramach gospodarki komunalnej. Taki stereotyp jest z wielu względów wręcz szkodliwy. Przede wszystkim jest on wyrazem fałszywego założenia, że zadania z zakresu gospodarki komunalnej można wykonywać, kierujac się logiką wolnego, niemal niczym nieskrępowanego rynku, którego swoistym symbolem jest spółka kapitałowa. Tymczasem tak nie jest. Najlepszym tego dowodem są różnego rodzaju prawne ograniczenia funkcjonowania spółek komunalnych. Przejawiaja się one w ograniczonym zakresie ich dopuszczalnego działania, konieczności świadczenia określonego pakietu usług komunalnych niezależnie od rentowności tych przedsięwzięć, a także w istotnym ustawowym zredukowaniu możliwości swobodnego kształtowania przez nie treści umów zawieranych z mieszkańcami danej społeczności lokalnej ${ }^{34}$. Wszystkie te uwarunkowania sprawiaja, że istota spółki komunalnej daleko odbiega od typowej spółki kapitałowej. W gruncie rzeczy mamy tu do czynienia z sui generis komunalnym przedsiębiorstwem użyteczności publicznej, do którego w kwestiach nieuregulowanych ustawodawca nakazał stosować Kodeks spółek handlowych. Pojawia się przy tym kolejne niepokojące założenie, że administracja może skutecznie uniknąć ciężaru wykonywania swych ustawowych zadań i innych krępujących ją ograniczeń, posługując się formą spółki prawa handlowego. Założenie to stwarza wielorakie zagrożenia dla interesów wspólnoty samorządowej i poszczególnych jej członków, a nawet dla samych pracowników takiej spółki ${ }^{35}$.

31 Zob. A. Stelmachowski, op. cit., s. 25.

32 Zob. A. Ohanowicz, Wolność umów w przyszłym polskim kodeksie cywilnym, „Ruch Prawniczy, Ekonomiczny i Socjologiczny” 6, 1926, z. 1, s. 283.

${ }_{33}$ Zob. R. Szczepaniak, Granice cywilnoprawnej metody regulacji..., passim.

${ }_{34}$ Zob. art. 4 ust. 1 pkt 2 oraz art. 10 ustawy z 20 grudnia 1996 r. o gospodarce komunalnej, Dz. U. 2016, poz. 573.

35 Zob. R. Szczepaniak, Spótka komunalna a spótka z udziałem Skarbu Państwa - szkic do charakterystyki porównawczej, w: A. Kidyba (red.), Spótka z udziałem Skarbu Państwa a Skarb Państwa, Warszawa 2015, s. 174-175 i 177-179. 


\section{Niebezpieczeństwa związane z metodą interdyscyplinarną}

Problematyka stosowania prawa prywatnego w sektorze publicznym niewątpliwie wymaga podjęcia badań o charakterze interdyscyplinarnym. Mamy tu bowiem do czynienia z zagadnieniami z pogranicza różnych dyscyplin prawniczych i nie należy a priori ograniczać się do dorobku jednej z dyscyplin nauk prawnych. Oczywiście chodzi tutaj o interdyscyplinarność w najwęższym tego słowa znaczeniu, tj. niewykraczająca poza obręb prawoznawstwa (integracja wewnętrzna nauk prawnych). Jednak w obrębie nauk prawnych istnieje deficyt nawet tak wasko pojętej interdyscyplinarności.

Należy jednak zauważyć, że z metodą interdyscyplinarną wiążą się również pewne zagrożenia i nie należy do niej mieć bezkrytycznego stosunku. Podejście interdyscyplinarne od wielu już lat jest propagowane w naukach społecznych. Można nawet mówić o wykształceniu się pewnej mody na interdyscyplinarnośćs ${ }^{36}$. W konsekwencji podejmowanie tematyki z pogranicza różnych dyscyplin prawoznawstwa może być postrzegane samo w sobie jako atrakcyjne i pożądane. To z kolei może prowadzić do swoistego pójścia na skróty, a więc rozpoczęcia badań bez dostatecznego przygotowania merytorycznego, tak jakby już sam fakt podjęcia takich badań stanowił autonomiczną wartośśc ${ }^{37}$.

Wydaje się jednak, że badania za pomocą metody interdyscyplinarnej są konieczne; nie ma innej drogi, jeśli chcemy rzetelnie rozwiązać szereg problemów teoretycznych z zakresu omawianej tematyki. Optymalnym rozwiązaniem może się więc okazać, aczkolwiek i ono nie jest pozbawione wad, tworzenie zespołów badawczych złożonych zarówno z cywilistów, jak i administratywistów ściśle ze sobą współpracujących.

\section{KWESTIA WOLNOŚCI UMÓW W SEKTORZE PUBLICZNYM}

W moim przekonaniu jest to zagadnienie, które nie doczekało się jeszcze kompleksowego rozwiązania ani w literaturze polskiej, ani zagranicznej. Można natrafić na zupełnie sprzeczne poglądy, począwszy od takich, które taka swobodę programowo neguja, do takich, w świetle których obowiązuje ona w tym środowisku, jakim jest sektor publiczny, zasadniczo bez żadnych istotnych modyfikacji, poza przypadkami, gdy wyraźny przepis prawa ją ogranicza. Powodem trudności, jakie napotykamy przy analizie tego zagadnienia, jest jego wyjątkowa złożoność. Pojawia się problem kompromisu pomiędzy konstytucyjna zasadą związania władzy publicznej prawem (art. 7 Konstytucji) a potrzeba zapewnienia określonej operatywności administracji dla uzyskania maksymalnej efektywności jej działań. Przy rozpatrywaniu tego zagadnienia niewątpliwie należy też mieć na uwadze potrzebę zapewnienia bezpieczeń-

${ }^{36}$ Zob. Z. Kloch, Interdyscyplinarność w naukach spotecznych $i$ humanistycznych - możliwości i ograniczenia, www.obta.uw.edu.pl/pl-61 [dostęp: 21.11.2016].

${ }^{37} \mathrm{Na}$ temat niebezpieczeństw związanych z badaniami interdyscyplinarnymi zob. J. Łakomy, Pojęcie integracji zewnętrznej nauk prawnych, Wrocławskie Studia Erazmiańskie. Zeszyty Studenckie. Studia Erasmiana Wratislaviensia, Wrocław 2009, s. 63. 
stwa obrotu prawnego. Ten ostatni problem wiąże się z kwestią ewentualnych skutków prawnych zawarcia umowy przez nieupoważniony do tego podmiot prawa publicznego. Ponadto problematyka swobody umów w sektorze publicznym nierozerwalnie splata się z tak fundamentalnymi kwestiami, jak zakres zdolności prawnej podmiotów prawa publicznego i zakres praw podmiotowych im przysługujących, co dodatkowo potęguje jej złożoność. Jeżeli bowiem ustawodawca zamierza ograniczyć czy wyłączyć możliwość występowania jakiegoś podmiotu w obrocie prawnym, może to z technicznego punktu widzenia uczynić w trojaki sposób. Ustawodawca może ograniczyć jego zdolność prawną i zdolność do czynności prawnych, czyniąc go niezdolnym do dokonywania czynności prawnych określonego rodzaju. W tle bezsprzecznie kołacze koncepcja specjalnej zdolności prawnej osoby prawnej ${ }^{38}$. Może także wprowadzić specjalną kategorię praw podmiotowych przysługujacych temu podmiotowi, charakteryzujacca się daleko ograniczonymi uprawnieniami w zakresie rozporządzania nimi i w korzystaniu z nich. Może wreszcie nie tyle ograniczyć zdolność prawną czy też stworzyć specjalną ograniczoną kategorię praw podmiotowych, ile ograniczyć czy też wyłączyć swobodę umów w odniesieniu do takiego podmiotu. Ostatecznie każde z tych rozwiązań prowadziłoby do tego samego celu ${ }^{39}$.

\section{KONSTYTUCYJNE GRANICE CYWILNOPRAWNEJ METODY REGULACJI STOSUNKÓW SPOŁECZNYCH}

Wywody poświęcone stereotypom narosłym wokół podziału na prawo publiczne i prawo prywatne, a także dotyczące swobody umów w sektorze publicznym inspiruja nieodparcie do postawienia pytania o konstytucyjnoprawne granice cywilnoprawnej metody regulacji stosunków społecznych, w których jedna ze stron jest tzw. podmiot prawa publicznego. Zachodzi ryzyko, że nieskrępowana aktywność tych podmiotów w obrocie cywilnoprawnym mogłaby prowadzić do najróżniejszych nadużyć, w szczególności do omijania konstytucyjnych standardów demokratycznego państwa prawnego. Przeważa bowiem, zwłaszcza w środowisku praktyków (w tym w orzecznictwie), pogląd, że podmiot prawa publicznego działajacy w formach typowych dla prawa cywilnego z umową na czele staje się takim samym uczestnikiem obrotu cywilnoprawnego jak jednostka prywatna. W konsekwencji podmiot ten zwolniony jest wówczas z krępujących go zasad i standardów adresowanych do organów władzy publicznej ${ }^{40}$. Na tym właśnie polega opisywane od dawna w literaturze

${ }^{38}$ Zob. R. Szczepaniak, Specjalna zdolność prawna osób prawnych. Relikt poprzedniego systemu czy źródło inspiracji?, „Kwartalnik Prawa Prywatnego” 2009, z. 3, s. 621 i n.

${ }^{39}$ Zob. idem, Glosa do uchwaty SN z 6 czerwca 2014 r. III CZP 24/14, OSP 2015, z. 3, s. 432.

${ }^{40}$ Przejawem takiego myślenia jest np. następująca wypowiedź SN: „Wskazanie na formę umowy jest przykładem wykorzystania przez ustawodawcę instrumentów prawa cywilnego w dziedzinie dysponowania funduszami strukturalnymi i wskazuje na ulokowanie podmiotów zawierających ją na równorzędnych pozycjach w ramach stosunku prawnego nawiązanego w ten sposób”. Zob. wyrok SN z 11 maja 2012 r., II CSK 545/11, OSP 2014, z. 2, poz. 17 z glosą R. Szczepaniaka, s. 229. 
niemieckiej zjawisko „ucieczki administracji od prawa administracyjnego" ${ }^{1}$. W tym miejscu należy postawić tezę, że podmioty prawa publicznego powinny kierować się tymi standardami niezależnie od formy prawnej, w jakiej prowadzą swoją aktywność. W szczególności zawarcie przez taki podmiot umowy nie powinno osłabiać czujności sądów i w konsekwencji nie powinno prowadzić do przyjęcia przez nie założenia, że podmiot ten stał się takim samym uczestnikiem obrotu cywilnoprawnego, jak jednostka prywatna. Skutkiem takiego założenia może być szkodliwa fikcja „cywilnoprawnej równości stron”. Zwraca na to uwagę Trybunał Konstytucyjny w wyroku z 27 maja 2014 r. Z wywodu przeprowadzonego przez TK można wywieść wniosek, że pytanie o konstytucyjnoprawne granice cywilnoprawnej metody regulacji jest adresowane zarówno do ustawodawcy, jak i do organów stosujących prawo ${ }^{42}$.

\section{KWESTIA POTRZEBY WYODRĘBNIENIA PRAWA CYWILNEGO SEKTORA PUBLICZNEGO (WNIOSKI KOŃCOWE)}

Niejednokrotnie specyfika podmiotów prawa publicznego sprawia, że pewne konstrukcje czy instytucje wypracowane w klasycznej cywilistyce przestają być w tym środowisku, jakim jest sektor publiczny, skuteczne czy też adekwatne do jego potrzeb. Powyższa uwaga dotyczy tak kluczowych instytucji, jak własność czy inne majątkowe prawa podmiotowe, zdolność prawna czy odpowiedzialność deliktowa. Przynajmniej częściowo zmieniają one swój kształt i naturę w odniesieniu do podmiotów prawa publicznego, a niekiedy nawet tracą rację bytu. Niedostrzeganie tych zjawisk sprawia, że może dochodzić do różnego rodzaju nieporozumień czy nadużyć. W skrajnym przypadku ta modyfikacja instytucji klasycznej cywilistyki w sektorze publicznym może prowadzić nawet do pogwałcenia czy też demontażu fundamentalnych zasad i konstrukcji będących dziedzictwem naszej kultury prawnej oraz do odwrócenia znaczenia pojęć prawnych. To z kolei może ponadto prowadzić do dezorientacji członków społeczeństwa i osłabienia zaufania do państwa i tworzonego przez nie prawa. Jednym z najbardziej spektakularnych przykładów

41 Zob. przypis 26.

${ }^{42}$ P 51/13, Dz. U. z 3 czerwca 2014 r., poz. 735; OTK-A 2014, z. 5, poz. 57. W uzasadnieniu tego wyroku znalazł się następujący wywód: „Trybunał zwraca przy tym uwagę, że ustawodawca ma swobodę wyboru trybu, w jakim Urząd będzie procedował, oraz podstaw finansowania działalności Urzędu. Nie jest rolą Trybunału rozstrzyganie, czy Urząd ma funkcjonować według reguł prawa prywatnego, na podstawie umów z klientami, czy też ma pozostać w reżimie publicznoprawnym. Nieakceptowalne konstytucyjnie jest jednak wprowadzenie obligatoryjnego trybu administracyjnego na etapie rejestracji i kontroli urządzeń objętych dozorem (a zarazem i podmiotów eksploatujących te urządzenia), z jednoczesnym stworzeniem - na kolejnych etapach działania Urzędu - fikcji cywilnoprawnej równości stron. Takie postępowanie, teoretycznie sankcjonujące nieuprawnione działania legislacyjne Ministra Gospodarki, mogłoby być również uznane za naruszające proklamowaną konstytucyjnie wolność działalności gospodarczej”. 
jest problematyka otwartych funduszy emerytalnych. Nowelizacja z $2013 \mathrm{r}$. ustawy z 28 sierpnia 1997 r. o organizacji i funkcjonowaniu funduszy emerytalnych ${ }^{43} \mathrm{w}$ istotnym stopniu zredukowała majątek zgromadzony $\mathrm{w}$ otwartych funduszach emerytalnych przez umorzenie obligacji państwowych zakupionych przez te fundusze. Pomimo dominującego poglądu, że majątek zgromadzony w otwartych funduszach emerytalnych nie należy do państwa ani innej państwowej osoby prawnej, TK w wyroku z 4 listopada 2015 r. ${ }^{44}$ nie dopatrzył się naruszenia konstytucyjnej zasady chroniącej własność w działaniach ustawodawcy, który pozbawił otwarte fundusze emerytalne istotnej części majątku. Z uzasadnienia wyroku wyłania się wielce niejasny kształt prawa własności do mienia zgromadzonego w otwartych funduszach emerytalnych. Nasuwa się wniosek, że charakter tego prawa majątkowego w tym przypadku jest na tyle hybrydowy a jednocześnie instrumentalny, iż kwestia ta wymyka się z metodyki klasycznej cywilistyki. Trybunał wyraża myśl, że istoty problemu otwartych funduszy emerytalnych nie można rozpatrywać w kontekście konstytucyjnego prawa do ochrony własności, a tym samym nie można domagać się ochrony tak rozumianego prawa, jako prawa nabytego, lecz w kontekście gwarancji określonych w art. 67 ust. 1 Konstytucji, tj. zapewnienia zabezpieczenia społecznego obywatelom ${ }^{45}$. Tak więc w ujęciu zaprezentowanym przez TK własność to tylko narzędzie swobodnie używane przez ustawodawcę do realizacji celów publicznych.

Wskazane doniosłe procesy i zjawiska związane ze stosowaniem prawa prywatnego $\mathrm{w}$ sektorze publicznym oraz towarzyszące im problemy teoretyczne i praktyczne sprawiaja, że w niektórych państwach europejskich podkreślana jest potrzeba ukształtowania pewnej subgałęzi prawa prywatnego poświęconej sektorowi publicznemu. W doktrynie niemieckiej dla jej nazwania ukuto termin Verwaltungsprivatrecht $t^{46}$. Przy czym niekoniecznie musi tu chodzić o ingerencję ustawodawcy. Taka subgałą́ może kształtować się jako rodzaj tzw. prawa sędziowskiego, podobnie jak pierwotnie kształtowało się np. prawo konsumenckie. Niemniej w Holandii dostrzega się już zaczątki kształtowania się takiej subgałęzi w ustawach ${ }^{47}$. Tak jak subgałęziami prawa prywatnego sa prawo handlowe oraz prawo konsumenckie, tak również można by za nie uznać cywilnoprawne regulacje mające zastosowanie do podmiotów prawa publicznego.

Prawo cywilne jako regulator aktywności podmiotów prawa publicznego wymaga określonych modyfikacji i odstępstw w stosunku do tradycyjnej cywilistyki. Są one wymuszone specyfiką tych podmiotów. Bez ich dokonania może

${ }^{43}$ Zob. ustawa z 28 sierpnia 1997 r. o organizacji i funkcjonowaniu funduszy emerytalnych, Dz. U. 2013, poz. 989 ze zm. oraz ustawa z 6 grudnia 2013 r. o zmianie niektórych ustaw w związku z określeniem zasad wypłaty emerytur ze środków zgromadzonych $\mathrm{w}$ otwartych funduszach emerytalnych, Dz. U. 2013, poz. 1717.

${ }^{44}$ K 1/14, Dz. U. z 18 listopada 2015 r., poz. 1917.

${ }_{45}$ Zob. pkt 4.7 uzasadnienia wyroku TK z 4 listopada 2015.

${ }^{46}$ Zob. H. de Wall, op. cit., s. 35; D. Ehlers, Verwaltung in Privatrechtsform, Berlin 1984, s. $212 \mathrm{i} \mathrm{n.}$

${ }^{47}$ Zob. art. 3: 14 holenderskiego kodeksu cywilnego w zw. z art. 3: 1(2) holenderskiego General Administrative Law Act. Zob. G. Jurgens, F. van Ommeren, op. cit., s. 172 i n. 
bowiem dochodzić do naruszenia zasad i wartości konstytucyjnych w przypadku posługiwania się przez administrację cywilnoprawnymi formami działania. Taki pogląd zaczyna już powoli zyskiwać sobie uznanie w polskim prawoznawstwie. Dla przykładu kilka lat temu wyrażono w sposób przekonujący twierdzenie o potrzebie wykształcenia odrębnej podgrupy zasad współżycia społecznego uwzględniających odrębności relacji zachodzących między podmiotami publicznymi i jednostkami prywatnymi. Trafnie zwrócono uwagę na zasady ogólne zawarte w Kodeksie postępowania administracyjnego jako dobrą bazę do wykształcenia takich zasad ${ }^{48}$. Wobec braku ustawy - Część ogólna prawa administracyjnego, to właśnie k.p.a. odgrywa nadal rolę, jak to określił Zbigniew Janowicz, pewnego rodzaju magna charta w stosunkach między obywatelem i władzą publiczna ${ }^{49}$.

Należałoby rozważyć uwzględnienie specyfiki stosowania instytucji prawa cywilnego w sektorze publicznym w pracach nad nowym kodeksem cywilnym jak również nad ustawa - Przepisy ogólne prawa administracyjnego. W szczególności chodzi o wprowadzenie rozwiązań chroniących interesy jednostek wchodzących w relacje cywilnoprawne z podmiotami prawa publicznego przy jednoczesnym poszanowaniu interesu publicznego $0^{50}$. W konsekwencji celowe jest także wyodrębnienie stosownej specjalizacji w ramach nauki prawa cywilnego.

Należy zwrócić w tym miejscu uwagę na wprowadzone już wiele lat temu przez administratywistów rozróżnienie na prawo administracyjne sensu stricto i prawo administracji (prawo administracyjne sensu largo) ${ }^{51}$. W ten sposób sami administratywiści próbują objąć zakresem swych badań obszary dotychczas zastrzeżone dla cywilistyki. Posługując się tym rozróżnieniem, administratywiści polscy uzasadniaja np. podejmowanie przez siebie studiów nad odpowiedzialnością odszkodowawczą władz publicznych za szkody wyrządzone przez swych funkcjonariuszy, pomimo że w Polsce od dawna problematyce odpowiedzialności odszkodowawczej władz publicznych przypisywany jest charakter cywilistyczny. W takim rozróżnieniu można dopatrzeć się podobnej

${ }^{48}$ Zob. P. Stec, op. cit. s. 73.

${ }^{49}$ Zob. Z. Janowicz, Kodeks postępowania administracyjnego. Komentarz, Warszawa-Poznań 1992, s. 28.

${ }^{50}$ Zob. P. Stec, op. cit., s. 153. Warto w tym miejscu zwrócić uwagę na treść art. 3: 14 holenderskiego kodeksu cywilnego w zw. z art. 3: 1(2) General Administrative Law Act. Ostatnia ustawa obowiązująca w Holandii jest odpowiednikiem polskiego projektu ustawy Przepisy ogólne prawa administracyjnego, na co zreszta twórcy projektu opracowanego przez Komisję Sprawiedliwości i Praw Człowieka (Druk nr 3942 z 29 grudnia 2010 r.) w jego uzasadnieniu zwracaja uwagę. Ze wskazanego przepisu holenderskiego kodeksu cywilnego wynika, że kompetencje, które przysługują komukolwiek na podstawie przepisów prawa cywilnego, nie mogą być wykonywane z pogwałceniem pisanych lub niepisanych zasad prawa publicznego". Z kolei wskazany przepis holenderskiej ustawy: przepisy ogólne prawa administracyjnego stanowia, że zapisane w tej ustawie zasady odnoszace się do wydawania przez administrację aktów administracyjnych stosowane są również do innych form aktywności administracji, o ile tylko dadzą się te zasady pogodzić z naturą tych innych form”. Zob. R. Szczepaniak, Projekt ustawy „Przepisy ogólne prawa administracyjnego” widziany okiem cywilisty, „Ius Novum” 2015, nr 3, s. 139.

${ }^{51} \mathrm{Na}$ temat pojęcia „prawo administracji” zob. W. Taras, A. Wróbel, op. cit., s. 120. Na temat tego rozróżnienia zob. także A. de Laubadère, J. C. Venezia, Y. Gaudemet, Traité de droit administratif, Paris 1994, s. 20. 
myśli do tej, która skłania do wyodrębnienia podgałęzi prawa prywatnego poświęconej podmiotom sektora publicznego. Wydaje się jednak, że samo ujęcie prawa w administracji nie załatwia problemu; potrzebne jest tutaj zaangażowanie również cywilistów, gdyż cechują się oni inną wrażliwością badawczą i inaczej rozkładają akcenty; mówimy przecież o stosowaniu instytucji prawa cywilnego, tyle że w specyficznym środowisku, jakim jest sektor publiczny. W żadnym wypadku nie należy jednak kontynuować czy też inspirować quasi-rywalizacji między cywilistami i administratywistami sprowadzającej się do prób przejmowania na wyłączność poszczególnych instytucji i pól badawczych. Wielce pożądane jest bowiem podjęcie skoordynowanych badań nad takimi instytucjami stosowanymi w administracji publicznej zarówno przez cywilistów, jak i administratywistów.

dr hab. Rafat Szczepaniak

Uniwersytet im. Adama Mickiewicza w Poznaniu

rafalsz@amu.edu.pl

\section{THE KEY ISSUES OF THE APPLICATION OF PRIVATE LAW IN THE PUBLIC SECTOR}

\section{Sum mary}

The article is a synthetic presentation of the key issues associated with the use of private law in the public sector. In the author's opinion, at least some of these problems have methodological dimensions. They include the issues that have developed around the traditional division into public and private law. Treating this division as an absolute value and perceiving it as a dichotomous division contributes to creating certain barriers in the way one thinks about law. These barriers are in turn the cause for the formation of different kinds of stereotypes, such as the stereotype of the 'good civil law' and the 'bad administrative law', the stereotype of the contract as an instrument for regulating social relationships which is always better than an administrative decision; the stereotype of commercial companies as organisational entities that are always better than state-owned enterprises.

The key issues also include the freedom of contract in the public sector. This matter seems to lack a comprehensive solution in Polish as well as foreign science of law. The problem of constitutional limits of civil methods of regulating social relationships is also noted.

In conclusion a thesis is put forward on the need for developing a separate branch of private law devoted to the use of private law in the public sector, taking into account the normative, scientific and educational aspects. 
